\title{
Analysis of day-ahead generation diagram in power network consisting of renewable energy sources
}

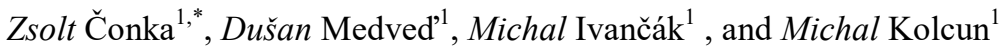 \\ ${ }^{1}$ Technical University of Košice, Department of Electric Power Engineering, Mäsiarska 74, 04001 \\ Košice, Slovakia
}

\begin{abstract}
This article deals with the analysis of a day-ahead generation diagram in specific part of a power network with renewable energy sources. As a renewable energy source a photovoltaic power plant was chosen. Input data for a day-ahead analysis was obtained from the database of previous measurement that was realised on the existing configuration in off-grid network at the department of authors. The simulation network was created in Matlab/Simscape Power System environment that consisted of rotating generators (for regulation of generated power due to fluctuated power generation from photovoltaic sources) and photovoltaic power plant of variable energy generation and loads. The results refer to a necessity to consider the previous measured data of the weather for prediction of future expectation of a day-ahead load diagram.
\end{abstract}

\section{Introduction}

This article presents the results of the simulation of the impact of a photovoltaic power plant on a small off-grid. Photovoltaic power plant and diesel generators are used as an energy source. With respect to power consumption, the effect of connection/disconnection of a dynamic and static load on generation/consumption balance is described. Several circuits were simulated to verify some network phenomena. Variables as frequency, voltage, power generation, and power consumption are monitored. For the purpose of production prediction on the following day, data from the meteorological station installed at the Department of Electric Power Engineering in Košice and data from the Slovak Hydrometeorological Institute were used.

Simscape Power Systems, a Matab Simulink extension, was used to simulate these phenomena. To reduce the impact of transient phenomena a simple solution has been developed based on the simulation analysis. A short time interval has also been chosen because the results recorded in the matrices are of certain accuracy and can be processed by common standard computational techniques.

* Corresponding author: dusan.medved@tuke.sk 


\section{Description of the network model in the environment of simscape power systems}

\subsection{Photovoltaic field}

Another source of electrical power that has been implemented in this paper is photovoltaic (PV) panels. The PV array is located in Simscape Power Systems block to simulate the photovoltaic panels. That's why the LG Electronics LG300N1-G3 photovoltaic panel has been selected. The label data of the modelled PV module are shown in Table 1. Module data for photovoltaic panel

Table 1. Module data for photovoltaic panel.

\begin{tabular}{|c|c|c|c|}
\hline \multicolumn{4}{|c|}{ Module data of PV array: LG Electronics LG300N1C-G3 } \\
\hline $\begin{array}{c}\text { Max power } \\
{[\mathrm{W}]}\end{array}$ & 305.226 & $\begin{array}{c}\text { Cell number in module } \\
\text { (Ncell) }\end{array}$ & 96 \\
\hline $\begin{array}{c}\text { Open-circuit voltage } V_{\mathrm{oc}} \\
{[\mathrm{V}]}\end{array}$ & 64.2 & $\begin{array}{c}\text { Short-circuit current } \\
{[\mathrm{A}]}\end{array}$ & 5.96 \\
\hline $\begin{array}{c}\text { Voltage at max power } V_{\mathrm{mp}} \\
{[\mathrm{V}]}\end{array}$ & 54.7 & $\begin{array}{c}\text { Current at max power } I_{\mathrm{mp}} \\
{[\mathrm{A}]}\end{array}$ & 5.58 \\
\hline $\begin{array}{c}\text { Temperature coefficient for } \\
V_{\mathrm{oc}}\left[\% /{ }^{\circ} \mathrm{C}\right]\end{array}$ & -0.273 & $\begin{array}{c}\text { Temperature coefficient for } I_{\mathrm{sc}} \\
{\left[\% /{ }^{\circ} \mathrm{C}\right]}\end{array}$ & 0.062 \\
\hline
\end{tabular}
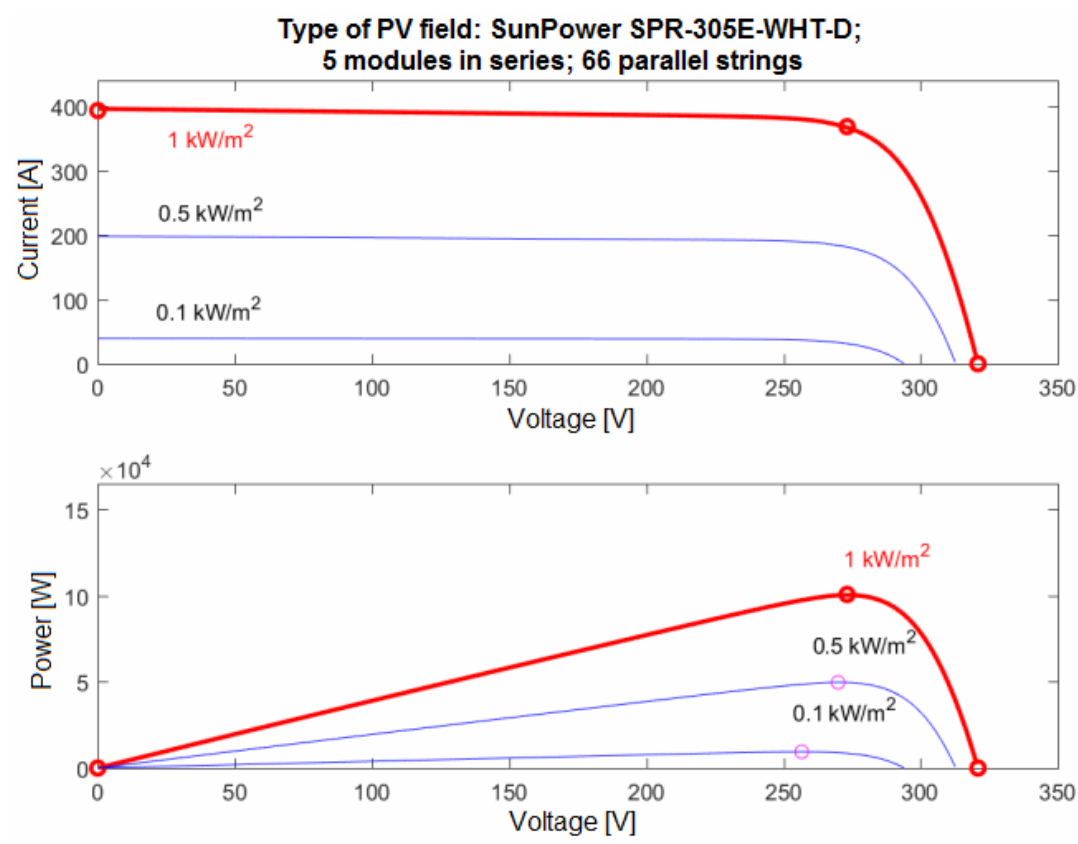

Fig. 1. $I-V$ and $P-V$ characteristics for $P V$ field at different solar radiation.

In the PV array block setting, the PV panels were connected to a field containing 66 parallel strings that serve 5 modules in series. The PV array has 2 inputs. The first input is the solar radiation reported in watts per $\mathrm{m}^{2}\left[\mathrm{~W} \cdot \mathrm{m}^{-2}\right]$, the second input is the temperature of the cell of the PV panel reported in Celsius degrees $\left[{ }^{\circ} \mathrm{C}\right]$. The output of the PV array is a DC voltage and a measuring port $m$ which contains the voltage and current of the PV cell, the diode current, the solar radiation and the temperature of the PV panel. Sunlight and 
solar panel temperature data were retrieved from the text file into the program. In Fig. 1 one can see the I-V and P-V characteristics for the proposed PV array, under the solar radiation at three different intensities: $1000 \mathrm{~W} \cdot \mathrm{m}^{-2}, 500 \mathrm{~W} \cdot \mathrm{m}^{-2}$ and $100 \mathrm{~W} \cdot \mathrm{m}^{-2}$ when the PV panel temperature is constant $\vartheta=25^{\circ} \mathrm{C}$.

Power output from the photovoltaic field is shown in Fig. 2. The DC current, which is generated by the PV panels, is controlled by a DC-DC amplifier, to which the MPPT controller operates. Subsequently, the current is changed to alternating current in a controlled three-phase VSC rectifier, including the inverter choke $R L$, the capacitive filter $C$, and the transformer TR1. The power is transferred out through a three-phase switch that is in the basic position "on". Block RL2 represents the power line by which is the PV field linked with the network. This model has been adapted and modified for the needs of this paper from MathWorks examples [8,9].

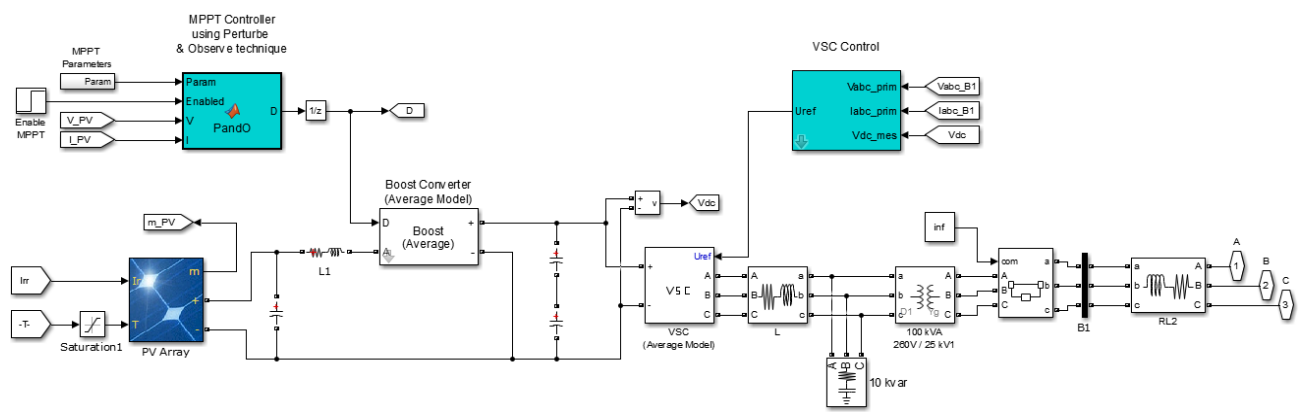

Fig. 2. Power output from photovoltaic panels.

\subsection{Description of power sources for simulation}

In the Simscape Power Systems, several electrical machines are implemented. Many of these electric machines can work in two states - as electricity generators or as motors, that is, as electric consumer appliances $[1,2]$.

A model of the synchronous machine with expressed poles was used. The synchronous generator is controlled by a hydraulic turbine combined with the PID control system and excited by the AC4A excitation system. The principal scheme of the G1 generator with a control and exciter system and generating output from the generator can be seen in Fig. 3 .

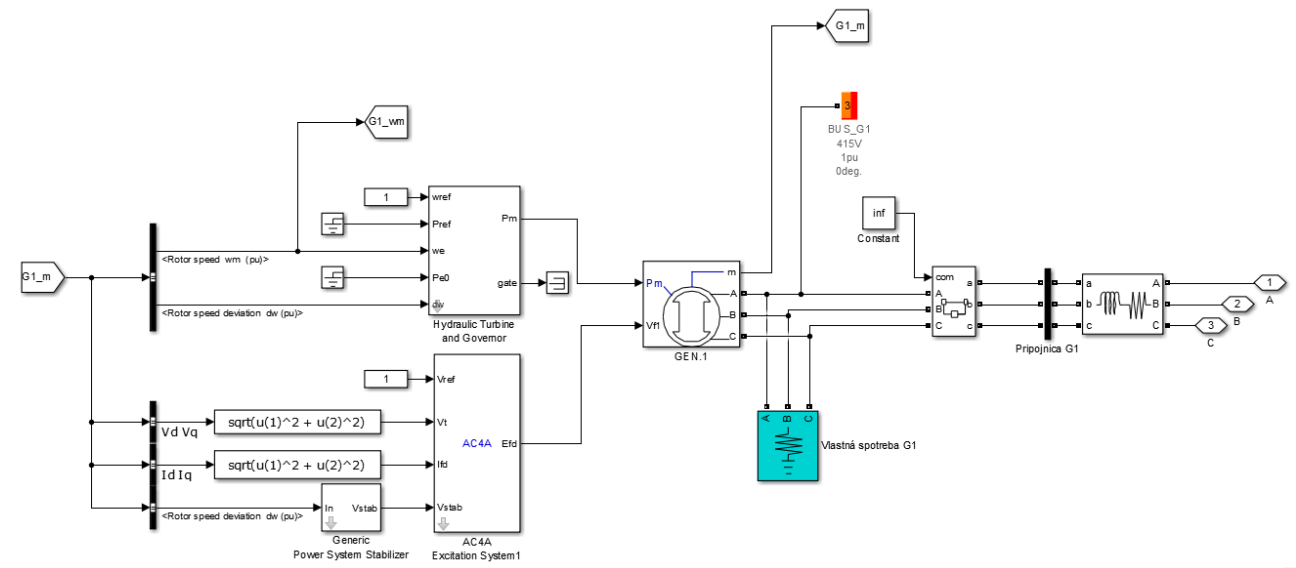

Fig. 3. Principal scheme of the G1 generator connection. 
Output of the synchronous generator is a three-phase voltage at the terminals of the machine $\mathrm{A}, \mathrm{B}$ and $\mathrm{C}$ and the measurement output marked with the letter $m$. The measurement output includes a vector with measured signals: stator currents, stator voltages, rotor angle deviation, rotor speed, electromagnetic torque, output active power $\mathrm{P}$, output reactive power Q, and so on. These signals receive feedback from the generator that is input to the exciter winding input and the hydraulic turbine with the control. The label data of the simulated generator are shown in Table 2.

Table 2. Data of the simulated generator.

\begin{tabular}{|c|c|c|c|c|c|}
\hline & \multicolumn{4}{|c|}{ Reactances [pu] } \\
\hline$P_{\mathrm{n}}$ & $250 \mathrm{~kW}$ & $x_{\mathrm{d}}$ & 2.84 & $x_{\mathrm{q}}$ & 2.44 \\
\hline$V_{\mathrm{n}}$ & $415 \mathrm{~V}$ & $x_{\mathrm{d}^{\prime}}$ & 0.18 & $x_{\mathrm{q}^{\prime}}$ & 0.36 \\
\hline$f_{\mathrm{n}}$ & $50 \mathrm{~Hz}$ & $x_{\mathrm{d}^{\prime \prime}}$ & 0.13 & $x_{\mathrm{q}^{\prime \prime}}$ & 0.09 \\
\hline \multicolumn{3}{|c|}{} & \multicolumn{2}{|c|}{0.0259375} \\
\hline \\
Stator resistance $R_{\mathrm{s}}[\mathrm{pu}]$ \\
Coefficient of inertia $H[\mathrm{~s}]$ & \multicolumn{2}{|c|}{0.01579} \\
\hline
\end{tabular}

In Fig. 4 there is a model of a hydraulic turbine with PID control. This model has 5 inputs and 2 outputs. Inputs include reference speed, instantaneous mechanical speed, speed deviation, reference power and instantaneous power output. The output is the mechanical power $P_{\mathrm{m}}$, which is also the input for the synchronous generator.

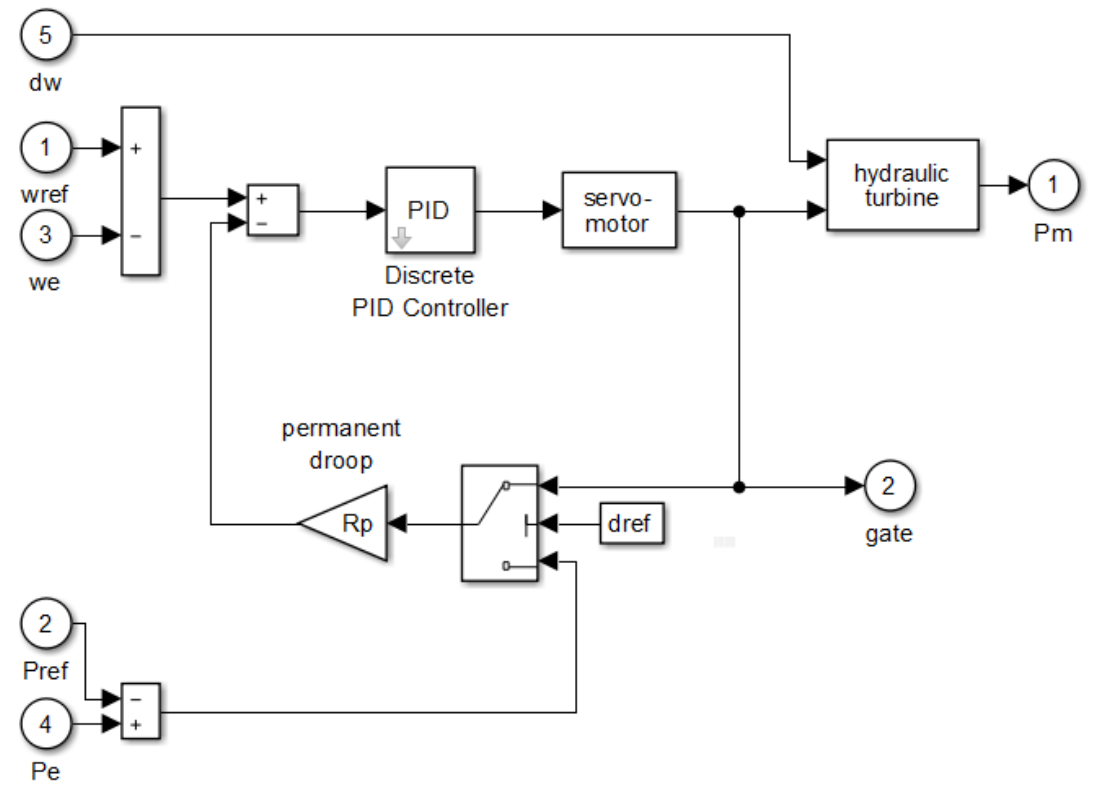

Fig. 4. Hydraulic turbine diagram with PID control.

In the mentioned model there was set the reference speed $\omega_{\mathrm{ef}}=1 \mathrm{pu}$, and the inputs of the immediate mechanical velocity $\omega_{\mathrm{e}}$ and the velocity variation $\mathrm{d} \omega$ were connected. This regulation ensures the regulation of the synchronous generator at the nominal frequency $f_{\mathrm{n}}=50 \mathrm{~Hz}$. Inputs of the reference mechanical power $P_{\text {ref }}$ and instantaneous power $P_{\mathrm{e} 0}$ were 
not connected. The circuit is set so that it does not take any feedback (or feedback from the gate output). It has been achieved that the turbine power was controlled only by rotor speed [7].

As the excitation system, the AC4A excitation system was used, which is an excitation system with thyristor rectifier for $\mathrm{AC}$ alternator. The excitation system generates the excitation voltage that is the output of this model.

Generating power from the generator into the grid consists of a three-phase circuit breaker and a busbar measuring the terminal voltage and the supplied power to the grid. Behind these terminals there is a power line simulated by the resistance $R$ and the inductance $L$. The mentioned generated power transmission into the output grid is shown in Fig. 2. Generator terminals are connected to the generator's own consumption, which consists of an active load of $P=12.5 \mathrm{~kW}$. This load has been used because the synchronous generator simulated as a current source cannot be in series with the induction element of the three-phase line with which the generator is connected to the grid.

\subsection{Static and dynamic loads}

Simscape Power Systems offers several types of loads. In this article we used the threephase series $R L C$ load and dynamic load phase. In both load they were given combined rated voltage and frequency network.

For a static three-phase load, the $P Q$ input is fed, which may be the same or specific for each load in all three phases. The static three-phase load also includes a voltage and current measurement, which is optional $[3,4,6]$.

For dynamic three-phase load, the $P Q$ power was entered at the beginning of the simulation. The $P Q$ power of a dynamic load can be controlled by an internal control that controls the amount of dynamic load based on the positive-sequence voltage component. If external control of power source is used, performance can be read from a file, and controlled by an external handling. The dynamic load contains also a measuring terminal $\mathrm{m}$, the output of which is a vector with a positive-sequence voltage component, an active power $P$ and a reactive power $Q[5,10]$.

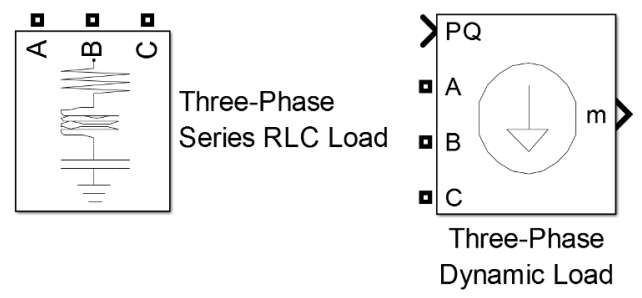

Fig. 5. Blocks in Simscape Power Systems representing loads.

The parameters of loads were read using a Matlab script. In Fig. 5, a proposed load block for the supply point A, is shown. On the left, the load line A1 and line A2 are shown, which are connected to the system via a three-phase circuit breaker and a power line simulated by the impedance $R_{\mathrm{a}}$ and $L_{\mathrm{a}}$. Line A2 consists of a purely ohmical load, because the dynamic load line A1 cannot be connected in series with the inductive element of the three-phase line, which is the supply point connected to the system. On the right, the reading of block of line load A1 is displayed. If init_const $=1$, the load, i.e. line A1 is set according to the vector from a text document. If init_const $=0$, the load is set to the constant value, which is set in the text document for time $t=0$. Current and voltage measurements were performed on bus-bar A. During the simulations, four consumption points $\mathrm{A}, \mathrm{B}, \mathrm{C}$ and $\mathrm{D}$ were considered. Each of these consumption points represents a part 
of the network. In some simulations, only static three-phase consumption points were used that were disconnected by a three-phase switch.
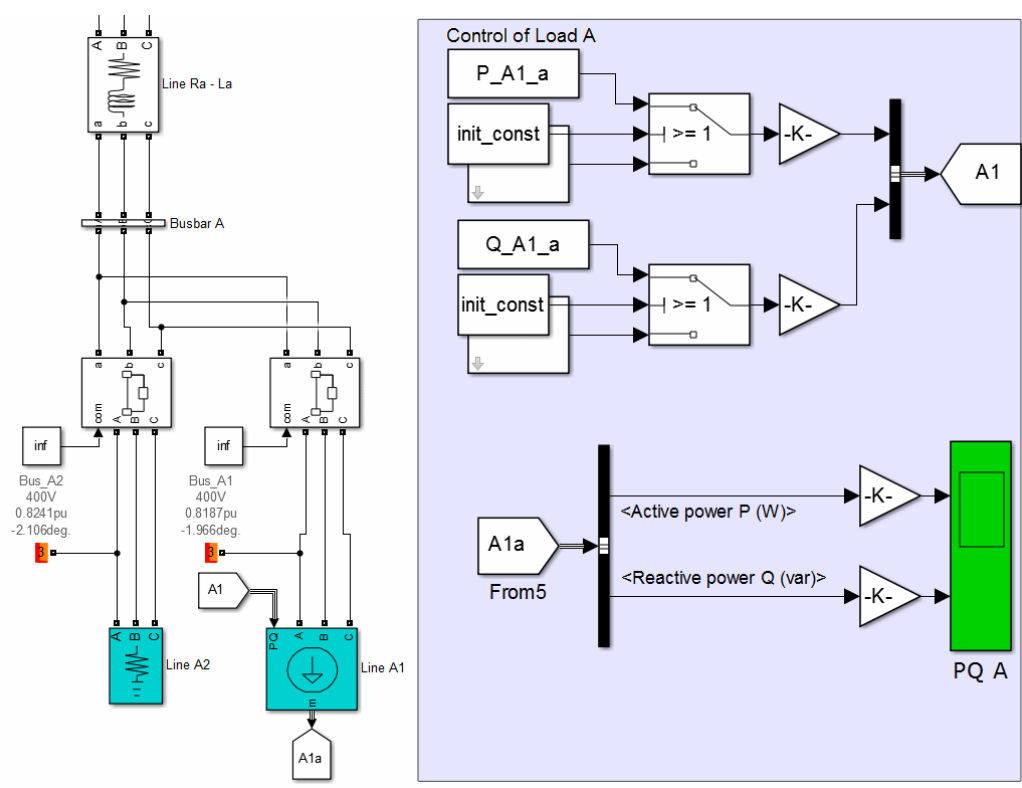

Fig. 6. Designed load block with control.

\subsection{Designed measurement in Simscape power systems}

In the simulations, electrical quantities were measured at selected locations in the network. Phase currents and voltages were measured using three-phase V-I measuring blocks, which were placed in front of loads and in front of the generators, resp. other sources. The measured output is the sinusoidal voltage/current depending on the time that has to be converted to the effective value (for comparison purposes). The scheme for measuring of the particular variables at the output of the G1 generator is shown in Fig. 7.

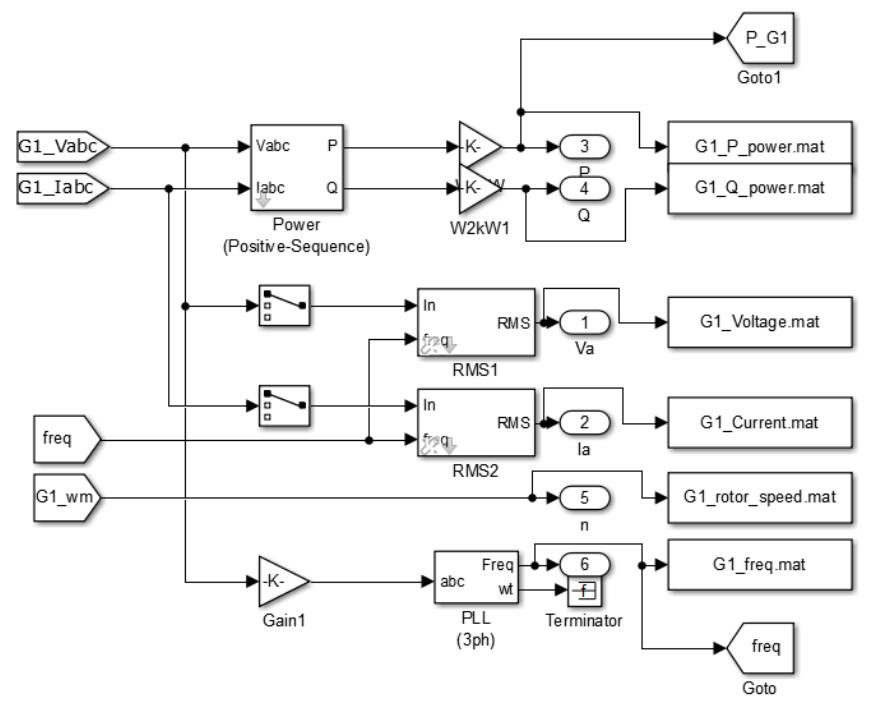

Fig. 7. Scheme for control and measuring of monitored quantities. 
The RMS current and voltage values for the L1 phase and the active and reactive power in the L1 phase were calculated from the measured currents and voltages.

\section{Mathematical calculation of off-grid network with renewable energy sources}

\subsection{Model of a steady-state off-grid network}

In the off-grid steady-state model, the main aim was to point out that if no changes were made to the scheme and the correct initialization conditions were set, the network's frequency did not change and was $50 \mathrm{~Hz}$. The phase voltage in phase L1 is equal to the portion of the line-to-line voltage and the square root of 3. If in a system were also considered losses on the line, the resulting voltage values were less than the expected $230 \mathrm{~V}$. In the system were considered large losses on lines, so the phase voltages at the terminals were lower, namely: $U_{\mathrm{a}_{-} \mathrm{A}}=220.5 \mathrm{~V}, U_{\mathrm{a}_{-} \mathrm{B}}=221 \mathrm{~V}, U_{\mathrm{a}_{-} \mathrm{C}}=223.1 \mathrm{~V}$, and $U_{\mathrm{a}_{-} \mathrm{D}}=227 \mathrm{~V}$. The demand current depends on the size of the load being connected at the consumption point (load). The active and reactive $P Q$ load was unchanged in the circuit.

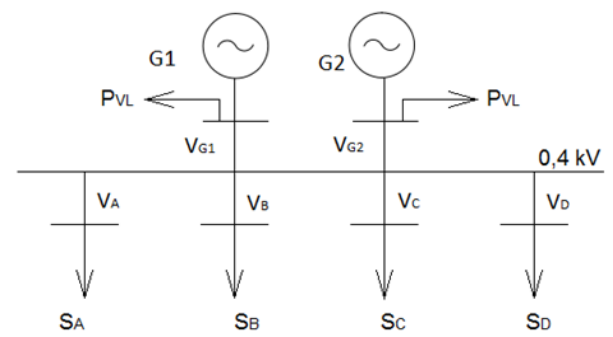

Fig. 8. The steady-state model diagram.

Table 3. Consumptions for simulation of steady-state of off-grid network.

\begin{tabular}{|c|c|c|c|c|c|}
\hline & \multirow{2}{*}{$\mathrm{U}[\mathrm{V}]$} & $\begin{array}{c}\text { Demand } \\
\text { power }\end{array}$ & $\begin{array}{c}\text { Power factor } \\
\cos \varphi\end{array}$ & \multicolumn{2}{|c|}{ Overhead line } \\
\cline { 5 - 6 } & & & $R[\Omega]$ & $L[\mu \mathrm{H}]$ \\
\hline $\begin{array}{c}\text { G1, Self- } \\
\text { consumption }\end{array}$ & 400 & $12.5 \mathrm{~kW}$ & 1 & 0.0025 & 11.27 \\
\hline $\begin{array}{c}\text { G2, Self- } \\
\text { consumption }\end{array}$ & 400 & $12.5 \mathrm{~kW}$ & 1 & 0.0025 & 11.27 \\
\hline Load A & 400 & $100 \mathrm{kVA}$ & 0.95 & 0.0402 & 71.1 \\
\hline Load B & 400 & $140 \mathrm{kVA}$ & 0.95 & 0.0268 & 47.4 \\
\hline Load C & 400 & $180 \mathrm{kVA}$ & 0.95 & 0.0134 & 23.7 \\
\hline Load D & 400 & 0 & 0.95 & 0.067 & 118.5 \\
\hline
\end{tabular}

\subsection{Model of off-grid network with dynamic load}

In this part of the simulation, there was modified model of loads. Instead of the loads modelled by the constant value, dynamic loads were used that were controlled by external input. Dynamic load operation is described in the previous chapter in part 1.2. During these simulations, two generators with a nominal power of $250 \mathrm{kVA}$ and four loads $\mathrm{A}, \mathrm{B}, \mathrm{C}$ and 
D were used in which the phase voltage and current in phase L1 and power value in L1 were measured.

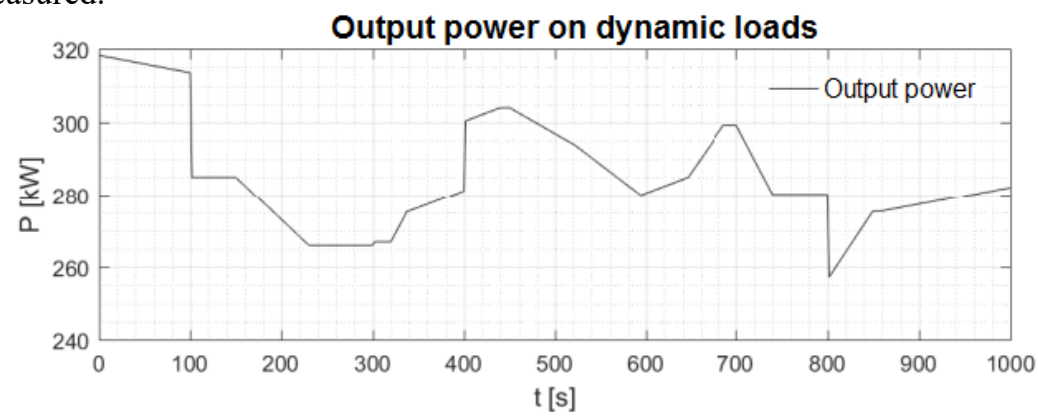

Network frequency

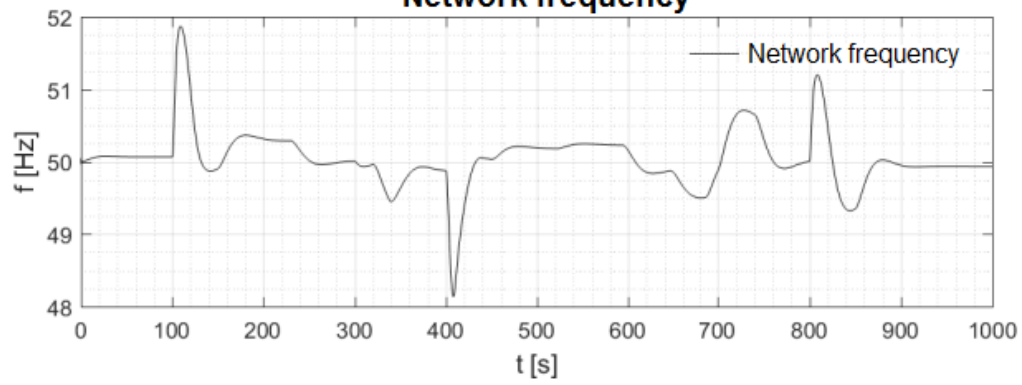

Fig. 9. Network frequency response to output power.

In Fig. 9, the consumed power is indicated by dynamic loads. Self-consumptions $(2 \times 12.5 \mathrm{~kW})$ and parasitic loads to dynamic loads $(3 \times 9.5 \mathrm{~kW}+4.75 \mathrm{~kW})$, which are purely resistive, have to be added to the total output power. These parasitic loads are in the system because dynamic loads and synchronous generators cannot be in series with an inductive element of three-phase power lines. Those are described by the $R L$ parameters listed in Tab. 4.

Table 4. Resistance and inductance of power lines in simulations with dynamic load.

\begin{tabular}{|c|c|c|}
\hline & $R[\Omega]$ & $L[\mu \mathrm{H}]$ \\
\hline G1 & 0.0025 & 11.27 \\
\hline G2 & 0.0025 & 11.27 \\
\hline A & 0.2010 & 355.50 \\
\hline B & 0.0268 & 47.40 \\
\hline C & 0.0134 & 23.70 \\
\hline D & 0.0670 & 118.50 \\
\hline PV & 0.0099 & 45.10 \\
\hline WT & 0.0099 & 45.10 \\
\hline
\end{tabular}

By a continual decreasing, respectively by increasing of the power consumption there has been observed, that the regulators of the synchronous generators respond to these changes, and there is a decrease, respectively increase in output power produced by synchronous generators, but the frequency is not regulated to the nominal value of $f_{\mathrm{n}}=50 \mathrm{~Hz}$. Thus, the frequency of the network will be short-lived at a different value near the nominal frequency due to the rate of decrease/increase of the consumed power. This can also be seen in Fig. 9, from 478 seconds to 595 seconds, the network's frequency was around $50.2 \mathrm{~Hz}$. From $900 \mathrm{~s}$ to $1000 \mathrm{~s}$ the network frequency was stable at values between 49.93 and $49.95 \mathrm{~Hz}$. 


\subsection{Simulation of off-grid network model with photovoltaic field}

All over the world there is a tendency for off-grid networks that are powered by diesel generators to replace them by renewable energy sources to reduce diesel consumption in diesel generators. In the mentioned model, photovoltaic panels with a total peak power of $100 \mathrm{~kW}$ were connected to the simulated off-grid network.

The Fig. 11 shows the solar radiation captured onto the photovoltaic field depending on the simulation time. At the beginning of the simulation, i.e. at time $t=0 \mathrm{~s}$, the solar radiation captured on the $\mathrm{PV}$ field, is $857.4993 \mathrm{~W} \cdot \mathrm{m}^{-2}$. At time $t=276 \mathrm{~s}$, solar radiation decreases to $266.2146 \mathrm{~W} \cdot \mathrm{m}^{-2}$, which is the first minimum of tested sunlight. At time $t=700 \mathrm{~s}$, a second low of $242.5764 \mathrm{~W} \cdot \mathrm{m}^{-2}$ solar radiation occurs. Both decreasing of solar radiation were due to increased cloud cover. The photovoltaic cell temperature was around $27^{\circ} \mathrm{C}$. These data were measured in August 2013 as a part of a hybrid photovoltaic system operated by the Department of Electrical Power Engineering, FEI TU in Košice. These data represent actual data under the conditions for which the electricity from the PV field was produced.

To measure meteorological quantities there was used meteorological station which is installed at Department of electric power engineering, at TUKE in Košice. Meteorological station consists of CMP6 Pyranometer and WXT520. WXT520 is a solid-state, all-in-one weather instrument that measures wind speed and direction, precipitation, barometric pressure, temperature, and relative humidity. The Pyranometer was used to measure the incident solar radiation. CMP6 is an ISO first-class pyranometer that monitors solar radiation for the full solar spectrum range. Fig.10 shows the results on-line visualization of the meteorological station in the SCADA system.
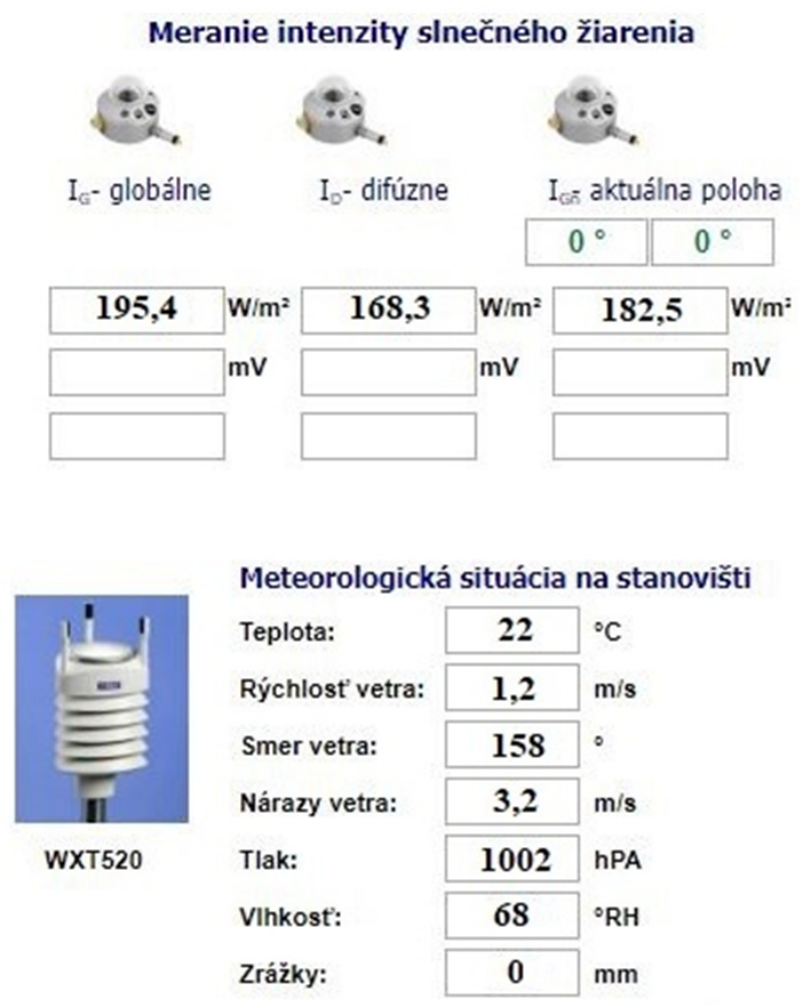

Fig. 10. Visualization of the meteorological station in the SCADA system. 


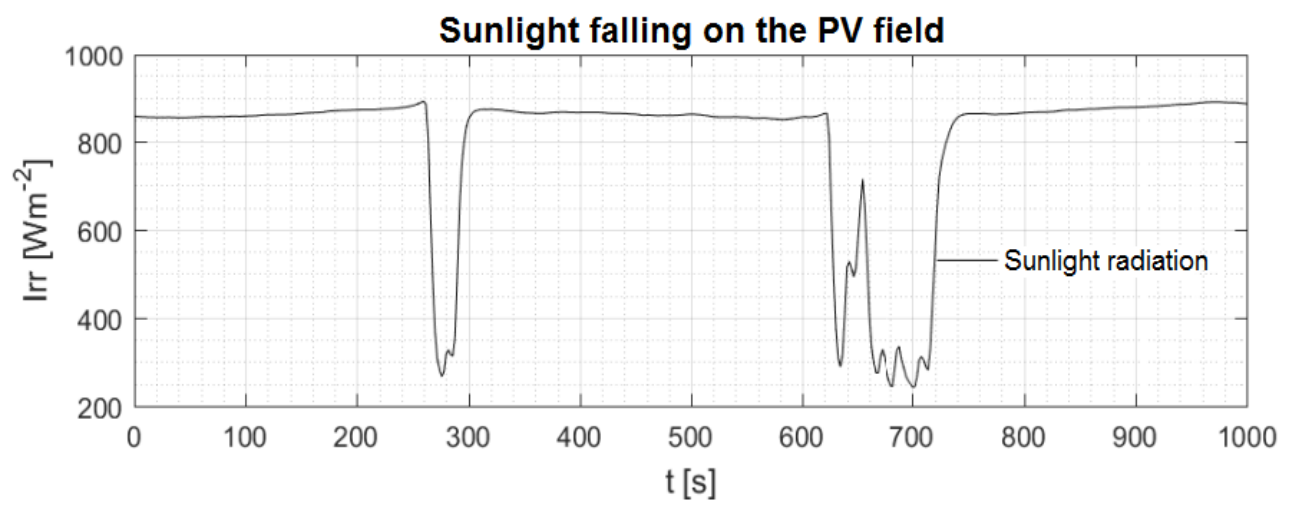

Fig. 11. Sunlight falling on the PV field.

\subsection{Simulation of off-grid network with PV-field and constant consumption}

In order to notice clearly the network's response to sudden drop in power output from the PV field, constant load values were set when simulating the photovoltaic field. In this case, the output produced by the diesel generators is adapted to the output produced by the PV field. The Fig. 11 shows the PV field response to the test climatic conditions. At the same time, Fig. 12 shows the response of generator No. 1. Generator No. 1 and 2 were connected in series, so generator 2 produces the same power as generator 1 . So when the output of the PV field drops by $60 \mathrm{~kW}$ due to meteorological conditions, both generators must start to produce $30 \mathrm{~kW}$ more power.

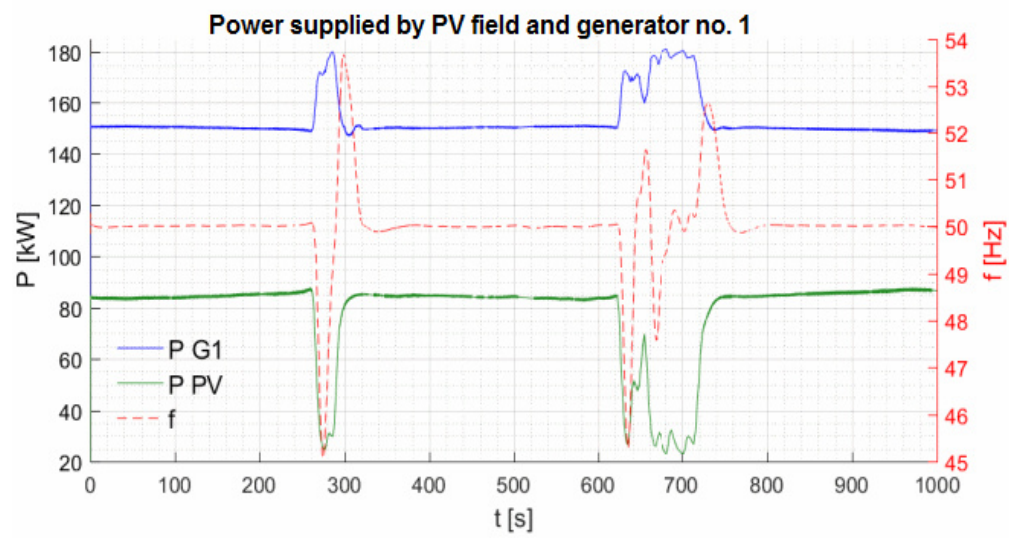

Fig. 12. The frequency of the network and the power output of the PV array with the generator no. 1 .

This simulation shows that the PV field is capable of producing relatively high power, but due to the increased cloud, short-term power failures can occur in the PV field output. The off-grid network simulation was implemented without any added controllers that would run the network on the load side. If an off-grid network was operated in this way, it is likely that the quality and reliability of electricity would be limited. In the simulation, the network frequency dropped from $50 \mathrm{~Hz}$ to below of $46 \mathrm{~Hz}$. While diesel generators are capable of operating in a wide frequency range, a mentioned rapid drop in frequency would be at risk. 


\section{Conclusion}

This paper presented the results of off-grid network simulations with consideration of photovoltaic power plant and without considering PV power plant. The simulated off-grid network consisted of two diesel generators with a nominal output of $250 \mathrm{~kW}$ and with loads representing by 4 off-grid sites. In case of load fluctuation, the generators regulate the generation according to consumption changes. Generators maintain a balance between generation and consumption. Generator were regulated by controlling of their hydraulic turbines.

The main problem of off-grid system is that, the photovoltaic power plant is unable to control the power generation, and their power generation is unstable. For the purpose of production prediction on the following day, data from the meteorological station installed at the Department of electric power engineering (at TUKE) and data from the Slovak Hydro Meteorological Institute were used. Generation of electricity by photovoltaic power plant is rapidly dependent on weather conditions. In case of unbalance between generation and consumption, the frequency changes. When generation is higher than consumption, the frequency increases and vice versa. Low or higher frequency has negative impact on electronic devices. Another problem is voltage fluctuation. Overvoltage can destroy electronic devices or shorten device lifetime. For this reasons it is very important to create such off-grid sites, where these quality indicators are maintained on their standardized limits.

This work was supported by the Ministry of Education, Science, Research and Sport of the Slovak Republic and the Slovak Academy of Sciences under the contract No. VEGA 1/0372/18.

\section{References}

1. Z. Čonka, et. al., Impact of renewable energy sources on stability of EWIS transmission system, In: $14^{\text {th }}$ Int. Conf. on Env. and El. En.: conf. proc.: Krakow, Poland, Danvers: IEEE, p. 75-79. ISBN 978-1-4799-4661-7, (2014)

2. R. Cimbala, L. Kruželák, S. Bucko, J. Kurimský, M. Kosterec, Influence of Electromagnetic Interference on Time-Domain Spectroscopy of Magnetic Nanofluids, In: EPE 2016. Danvers: IEEE, p. 279 - 282. ISBN 978-1-5090-0907-7, (2016)

3. M. Pavlík, Prediction of electricity price using RSI mechanism, In: Scientific Letters of Academic Society of M. Baludansky, Vol. 4, No. 6A p. 82-84. ISSN 1338-9432, (2016),

4. J. Zbojovský, P. Liptai, M. Moravec, Modelling and calculating the shielding effectiveness of building materials, In: Technical sciences and technologies. Vol. 6, no. 4 , p. 205-210. ISSN 2411-5363, (2016)

5. Ž. Eleschová, A. Beláň, B. Cintula, B. Bendík, Smart grids analysis - View of the transmission systems voltage stability, In EPE 2018. Brno: University of Technology, p. 37-42. ISBN 978-1-5386-4612-0, (2018)

6. D. Kaprál, P. Braciník, M. Roch, M. Höger, Optimization of distribution network operation based on data from smart metering systems, Electrical Engineering, Vol. 99, Issue 4, Springer, New York, USA, p. 1417-1428, ISSN 0948-7921, (2017)

7. J. Pálfi, P. Holcsik L. Pokorádi, Determination of Customer Number by Matrix Operations in Case of Network Failure In: IEEE 12th Int. Symposium on Applied Computational Intelligence and Informatics. Temesvar, Romania, 17-19 May 2018 IEEE Hungary Section, p. 555-560, ISBN:978-1-5386-4639-7, (2018)

8. MathWorks, Model hydraulic turbine and proportional-integral-derivative, $<$ https://www.mathworks.com/ help/ physmod/sps/powersys/ref/hydraulicturbineandgovernor.html >

9. MathWorks, Three-Level Bridge,

$<$ https://www.mathworks.com/help/physmod/sps/powersys/ref/threelevel bridge.html $>$. 
10. MathWorks, Average Model of a 100-kW Grid-Connected PV Array, $<$ https://www.mathworks.com/ help/physmod/sps/examples/average-model-of-a-100kw-grid-connected-pv-array.html > 